\title{
REFLECTIVE THINKING AND INQUIRY SKILLS AS PREDICTORS OF SELF- EFFICACY IN TEACHING MATHEMATICS
}

PROBLEMS

OF EDUCATION

IN THE $21^{\text {st }}$ CENTURY

Vol. 80 , No. 1, 2022

\author{
Mehtap Saracoglu \\ Siirt University, Turkey \\ E-mail: mehtapsarac@siirt.edu.tr
}

\begin{abstract}
This study aims to show to what extent the variables of reflective thinking, inquiry skill and mathematics teaching self-efficacy belief affect each other, to show their rates of explaining each other, and to show whether inquiry skill is a mediating variable in the relationship between reflective thinking and mathematics teaching self-efficacy belief. The data which were collected to test the hypotheses regarding the relationships to be shown were evaluated with structural equation modeling. A relational screening model was used in the research. The participants of the study were 304 prospective primary school teachers studying in their third and fourth years in the Basic Education Department of Education Faculties in two different state universities in Turkey. As data collection tools, the "Reflective Thinking Level Determination Scale", "Inquiry Skills Scale" and "Mathematics Teaching Efficacy Belief Instrument" were used. According to the results of the study, reflective thinking affects mathematics teaching selfefficacy belief positively and significantly and explains it significantly. Reflective thinking affects inquiry skills positively and significantly and explains it significantly. Inquiry skill affects mathematics teaching self-efficacy belief positively and significantly. Reflective thinking and inquiry skill together explain mathematics teaching self-efficacy belief highly and significantly. Inquiry skill has a partial mediating effect between reflective thinking and mathematics teaching self-efficacy belief.
\end{abstract}

Keywords: Inquiry skill, mathematics teaching, prospective primary school teachers, reflective thinking, teacher education

\section{Introduction}

Knowledge production, which has had a serious impact on the 21 st century, has caused changes and developments in many lines of work. While developing education policies, this change and development, the needs of the new generation and the business sector should be taken into account, and children should be educated in a way that will be appropriate for the age they will struggle in the future. For this reason, we need to raise individuals who question, research, have advanced problem-solving skills, high-level thinking skills, and high reflective thinking skills.

Mathematics education, which starts in the preschool period, has a significant place in individuals' lives and affects their attitudes towards mathematics positively and negatively. Therefore, primary school teachers have a great role in students' learning mathematics and developing self-efficacy perceptions (Arseven et al., 2015). Determining the mathematics selfefficacy beliefs of prospective primary school teachers is important in understanding their behaviors more correctly and increasing the academic achievement of students in the future.

Students' attitudes towards mathematics are shaped by the education they receive at school. Self-efficacy belief, which is considered a very important guide of the individual's behaviors and adaptation to the environment, is one of the important factors of the effective field of mathematics teaching. Self-efficacy belief, which is known to have a strong effect on the 
PROBLEMS

OF EDUCATION IN THE $21^{\text {st }}$ CENTURY Vol. 80 , No. 1,2022

214

achievement levels of individuals, is also an effective antecedent of their success in mathematics. Teachers' belief in self-efficacy affects the quality of teaching and has an important role in students' success (Çağırgan-Gülten et al., 2012). Toluk-Uçar et al. (2010) stated that students' beliefs about mathematics are subjective thoughts which arise from students' past mathematics experiences accepted as true by students. Therefore, students' beliefs about the mathematics they form in the first years of their formal education affect their whole education life. For this reason, mathematics teaching self-efficacy beliefs of primary school teachers, who will introduce students to mathematics and who will make them love mathematics, is very important. This is because one of the factors that affect students' success and attitude is the beliefs their teachers have and the learning environments they form according to their beliefs (Birgin, 2016). There is a close relationship between teachers' ability to teach mathematics effectively and their beliefs, perceptions, and self-efficacy towards mathematics teaching skills (Swars et al., 2007). Teachers who think that their self-efficacy perceptions about their teaching skills are important for students to be successful in providing effective teaching in the mathematics teaching process are more successful than teachers who think that their self-efficacy perceptions will not affect their success (Enochs et al., 2000). In other words, high self-efficacy perceptions of primary school teachers have a direct effect on students' academic achievement.

In its most general sense, reflective thinking is the individual's thinking deeply about the past/future and present experiences, questioning his/her learning/teaching and thinking process, and evaluating the self and thinking about what he/she can do to solve the problems as a result of this evaluation. While gaining learning experiences, students will try to make their learning processes productive by subjecting these experiences, their educational beliefs, and the knowledge they gain to constant questioning. Teachers will on the one hand make students question by guiding the use of this skill, while on the other hand, they will reflect on their teaching by examining their guidance process (Wilson \& Jan, 1993). According to Taggart and Wilson (2005), reflective thinking is the process of making informed and logical decisions on teaching issues and evaluating the consequences of these decisions. Norton (1997) defined creative thinking as an inquiry about the reasons, methods, materials, and consequences of educational practice. Reflective thinking, which is a high-level cognitive skill, has come to the fore as the main subject in constructivist understanding. This is because, through reflective thinking, which is an inquiry approach that cares about constructivism in teaching, individuals find the opportunity to reconstruct their experiences (Mahnaz, 1997). It is thought that reflective teachers' ability to reflect their actions in mathematics teaching practices will contribute positively to their problem-solving skills. In this sense, the necessity of reflective thinking skills in mathematics teaching emerges (Gözel \& Toptaş, 2017).

In mathematics teaching, primary school teachers should guide their students to reflective thinking during the process of problem-solving, they should ensure that their students question and evaluate what they do and establish cause-effect relationships between events and concepts (Baş \& Kıvılcım, 2013). According to Gipe and Richards (1992), reflective thinking is a questioning process, and it results in self-development. Schön (1987) emphasized that in courses given in educational institutions, students were generally prepared for problems that have only one solution and which are always well-defined, whereas they had to be educated as individuals with more advanced reflecting skills so that they could cope with complex and incompletely defined problems. According to Dewey (1933), reflective thinking is the ability of individuals to think effectively, consistently, and carefully about any thought or knowledge and a knowledge structure that supports reaching its intended results. Dewey (1933) stated that individuals with reflective thinking skills should be open-minded, willing, and responsible individuals. When a skill has to be measured, it is necessary to examine the actions which reveal that skill (Kızılkaya \& Asskar, 2009). In this context, it has been stated that one of the acts that show reflective thinking skills is inquiry (Dewey, 1933). According to Branch and Solowan 
(2003), since inquiry is a student-centered learning approach focused on asking questions,

thinking critically, and solving problems, it enables students to develop skills they may need all their lives and help them to cope with problems.

The foundations of the concept of inquiry go back to Socrates. The inquiry has been discussed by many researchers, including Dewey $(1926,1933,1938)$, Conant in the 1940s, Bruner, Suchman, Schwab, and Gagne in the 1960s, and Piaget and Lawson in the 1980s. Inquiry means seeking explanations or information by asking questions. In inquiry learning, students choose a subject that interests them, they study this subject in-depth, and they share what they learn. Students ask questions, analyze information, and they are active during the learning process; therefore, the inquiry is based on a constructivist learning approach. Inquiry skill engages students in the learning process; students take responsibility for their learning and thus maximize learning. Inquiry-based learning enables students to develop their skills of critical thinking, scientific processing, and problem-solving (Bell et al., 2005; Chung \& Behan, 2010). Llewellyn (2002) stated that the inquiry-based learning approach provides students with the necessary skills to become free individuals and lifelong learners. Inquiry skill helps students to develop lifelong learning skills. Lawson (2010) advocated that the inquiry-based learning approach develops students' creativity, academic achievement, critical thinking skills, and problem-solving skills.

There are studies in the literature that examined the effects of inquiry-based learning methods on students' academic achievement. Varlı and Uluçınar-Sağır (2019) concluded that inquiry-based learning approach has a significant effect on students' academic achievement, inquiry learning skills, and metacognition. Abdi (2014) examined the effects of the inquirybased learning method on students' academic achievement in a science lesson. It was found that the students who received education through inquiry-based learning got higher scores when compared with the students who were educated with the traditional method. Akpullukçu (2011) found that using practices in a research-based learning environment in science and technology lessons could be beneficial for students' academic achievement and developing students' attitudes towards the lesson. In literature, inquiry-based teaching has been applied in many courses and the efficacy of this teaching method has been examined in terms of different variables considered. It was found that inquiry-based teaching increased academic achievement, enabled students to develop positive attitudes for courses, ensured the permanence of information, developed logical thinking skills and scientific data processing skills and scientific process skills (Bağcaz, 2009; Balım et al., 2008; Budak Bayır, 2008; Çeliksöz, 2012; Davies et al., 2012; Duban, 2008; Erdoğan, 2005; Evrekli, 2010; Evren, 2012; Gençtürk, 2004; Güngör Seyhan, 2008; Kara, 2008; Küçük, 2012; Sağlam, 2012; Sözen, 2010; Şen, 2010; Taşkoyan, 2008; Timur, 2005).

There are also studies in the literature which discuss the reflective thinking skills of primary school teachers and prospective primary school teachers in terms of various variables. For example, Çelik and Dikmenli (2021) and Alkan and Gözel (2013) concluded that prospective primary school teachers had high reflective thinking tendency levels. Akar and Şahin (2020) and Kaf-Hasırcı and Sadık (2011) found that primary school teachers had high reflective thinking tendencies. Aras, Şiringül, and Park (2019) found that prospective teachers had high reflective thinking levels. Karapınar (2016) stated that inquiry-based learning environments were effective in prospective teachers' accessing knowledge with scientific validity and increasing scientific process skills that include the production process of knowledge.

The rapid change in science and technology, the changing needs of the individual and the society, the innovations and developments in learning and teaching theory and approaches also had a direct effect on the roles expected from individuals. It can be seen that in the primary mathematics lesson teaching program of our country, there are goals such as making an inquiry, making inferences about logical induction and deduction, thinking critically, 
PROBLEMS

OF EDUCATION

IN THE $21^{\text {st }}$ CENTURY Vol. 80, No. 1,2022

216

developing problem-solving strategies, making research, developing the power to produce and use knowledge (Ministry of National Education [MoNE], 2018). As the organizers of learning environments, teachers should possess the skills that students should have as specified in Turkish National Education Programs because it is teachers that will develop the reflective thinking and inquiry skills of students. Teachers cannot be expected to educate their students to have the skills they do not have. Therefore, primary school teachers who will build the future should have high-level skills defined as 21 st-century skills (creative-reflective-critical-scientific thinking, inquiry skill, problem-solving, communication, conflict solution, skills of using information and communication technologies). To be able to educate students with high inquiry skills and reflective thinking skills, primary school teachers, who are the implementers of the primary school program, should also have these skills. In this context, it becomes important to what extent reflective thinking and inquiry skills predict prospective primary school teachers' mathematics teaching self-efficacy beliefs. It is expected for prospective teachers who will graduate from the primary school teaching program to have high inquiry skills, high reflective thinking skills, and high self-efficacy perceptions towards mathematics. No known studies in literature explain the effects and impact of reflective thinking and inquiry-based learning on the development of mathematics self-efficacy for prospective primary school teachers. In this respect, the present study is of great importance.

\section{Research Aim and Research Questions}

In line with the literature on the relationship between reflective thinking, inquiry skills, and mathematics teaching self-efficacy, which are tried to be explained above, and the relationship between these three parameters the following hypotheses have been developed.

\section{Hypotheses:}

H1. Reflective thinking affects mathematics teaching self-efficacy belief positively and significantly.

H2. Reflective thinking explains the mathematics teaching self-efficacy belief meaningfully.

H3. Reflective thinking affects inquiry skills positively and significantly.

H4. Reflective thinking explains the inquiry skill meaningfully.

H5. Inquiry skill affects mathematics teaching self-efficacy belief positively and significantly.

H6. Reflective thinking and inquiry skills together explain mathematics teaching selfefficacy belief at a high level and meaningfully.

H7. Inquiry skill has a partial mediation effect between reflective thinking and mathematics teaching self-efficacy belief.

\section{Research Methodology}

\section{Background}

A relational screening model was used in the research. The relational screening model is a research model that aims to determine the existence and degree of change between two or more variables (Karasar, 2012). In this context, the study discussed the effects of prospective teachers' reflective thinking, inquiry skills, and mathematics teaching self-efficacy belief levels on each other and their levels of explaining each other. 


\section{Sample}

PROBLEMS

OF EDUCATION

IN THE $21^{\text {st }}$ CENTURY

Vol. 80 , No. 1,2022

217

The participants of the study were 304 prospective primary school teachers studying in their third and fourth years in the Basic Education Department of Education Faculties in two different state universities in Turkey in the 2019-2020 academic year. The study group was selected by the "criterion sampling" method, which is one of the purposive sampling methods. The basic understanding of the criterion sampling method is to study all cases that meet a predetermined set of criteria. The criteria or criteria mentioned here can be created by the researcher or a previously prepared criteria list can be used (Yıldırım \& Şimşek, 2013). The basic criteria of this study are to be registered in the basic education department of education faculties of the universities and to be studying in the 3rd or 4th grade. Also, for the structural equation model, the data must meet the multiple normality assumption. It is stated that the minimum sample size should be between 100 and 150 to meet this assumption (Hair et al., 1998). In line with the criteria given above, the participant group of the research was determined as 304 people, and this number is suitable for the research and statistical analysis. In terms of gender, $62.2 \%(f=189)$ of the participants were "female" and $37.8 \%(f=115)$ are "male". While $18.1 \%(f=55)$ of the participants were in the " 20 and less" age group, $81.9 \%(f=249)$ were in the "21-30 age group". In terms of grade level, $54.6 \%$ of the participants $(f=166)$ were studying in the $3^{\text {rd }}$ grade while $45.4 \%(f=138)$ were in the $4^{\text {th }}$ grade.

Instrument and Procedures

\section{Data Collection Tools}

As data collection tools, "Reflective Thinking Level Determination Scale", "Inquiry Skills Scale" and "Mathematics Teaching Efficacy Belief Instrument" were used. More detailed information on these scales, as well as confirmatory factor analysis results for the scales, are given below.

\section{Reflective Thinking Level Determination Scale}

This scale was developed by Kember et al. (2000) in order to measure the reflective thinking skill levels of students at the end of a lesson and was adapted into Turkish by Başol and Evin-Gencel (2013). It consists of 4 factors and 16 items: habit (4 items), understanding (4 items), reflecting (4 items) and critical reflecting (4 items). The Cronbach-alpha value calculated for the total of the scale whose validity and reliability studies were conducted by Başol and Evin-Gencel (2013) is .77. In the scale scoring is done as follows; 5=Strongly Agree, 4=Agree, $3=$ Neutral, $2=$ Disagree, $1=$ Strongly Disagree. Based on the data obtained from this study, Cronbach-alpha values for each factor in the scale and the entire scale were calculated. While Cronbach-alpha reliability coefficients were .70 for "Habit"; .74 for "Understanding", .75 for "Reflecting" and .77 for "Critical reflecting", it was .79 for the total of the scale.

\section{Inquiry Skills Scale}

The Inquiry Skills Scale, which aims to measure the inquiry skills of prospective school teachers, was developed by Aldan-Karademir and Saracaloğlu (2013). The scale consists of a total of 3 factors and 14 items, namely getting information (6 items), checking information ( 5 items), and self-confidence ( 3 items). The Cronbach-alpha value calculated for the sum of the scale by Aldan-Karademir and Saracaloğlu (2013) is .82. In scale scoring; Always=5, Often $=4$, Occasionally $=3$, Rarely $=2$, Never $=1$ points. Based on the data obtained from this 
PROBLEMS

OF EDUCATION

IN THE $21^{\text {st }}$ CENTURY Vol. 80, No. 1, 2022

218

study, Cronbach-alpha values for each factor in the scale and the entire scale were calculated. While the Cronbach-alpha reliability coefficients were .73 for "Getting Information", .70 for "Checking Information" and .82 for "Self-Confidence", they were .83 for the total scale.

Mathematics Teaching Efficacy Belief Instrument

The scale, which was developed by Enochs et al. (2000) and adapted into Turkish by Hacıömeroğlu and Şahin-Taşkın (2010), to determine the efficacy beliefs of primary school teachers regarding mathematics teaching consists of a total of 3 sub-dimensions and 17 items; personal competence (6 items), the role of the teacher in effective teaching ( 7 items) and teaching performance (4 items). The Cronbach-alpha value calculated for the total of the scale whose validity and reliability studies were conducted by Hacıömeroğlu and Şahin-Taşkın (2010) is .712. In the scale scoring, it is evaluated as 5=Strongly Agree, 4=Agree, 3=Undecided, 2=Disagree, $1=$ Strongly Disagree. Based on the data obtained from this study, Cronbach-alpha values for each factor in the scale and the entire scale were calculated. While the Cronbachalpha reliability coefficients are .80 for "Personal competence", .82 for "The role of the teacher ineffective teaching" and .72 for "Teaching performance", they are .86 for the total scale.

Confirmatory factor analysis (CFA) was performed to test the validity of the scales used. The results obtained as a result of confirmatory factor analysis are shown in the table below (Table 1).

\section{Table 1}

The Results of Confirmatory Factor Analysis of Scales

\begin{tabular}{|c|c|c|c|c|c|c|c|c|c|}
\hline${ }^{*}$ Fit Indices & $\Delta \chi^{2}$ & $d f$ & $\Delta \chi^{2} / d f$ & RMSEA & SRMR & GFI & CFI & AGFI & $\mathrm{NFI}$ \\
\hline $\begin{array}{l}\text { The Scale for } \\
\text { Determining the Level of } \\
\text { Reflective Thinking }\end{array}$ & 316.22 & 112 & 2.823 & .072 & .056 & .912 & .946 & .900 & .926 \\
\hline The Inquiry Skills Scale & 214.16 & 74 & 2.894 & .074 & .058 & .924 & .959 & .903 & .930 \\
\hline $\begin{array}{l}\text { The Mathematics } \\
\text { Teaching Efficacy Belief } \\
\text { Instrument }\end{array}$ & 319.44 & 124 & 2.576 & .071 & .076 & .908 & .912 & .903 & .908 \\
\hline
\end{tabular}

As a result of the confirmatory factor analysis, in terms of multivariate (Mardia) values, the critical rate (c.r.) for "The Scale for Determining the Level of Reflective Thinking" was 42.246, the critical rate for "The Inquiry Skills Scale" (c.r.) was 44.325, and the critical rate (c.r.) for "The Mathematics Teaching Efficacy Belief Instrument" was 46.632. Since there were no items with a critical ratio greater than 10 for all three scales, all items were included in the analysis in the next step. In addition, when Table 1 is examined, it is seen that the fit values for the scales are at an acceptable level.

\section{Data Analysis}

The data obtained as a result of the application of the scales used in the research were entered into the SPSS (Statistical Package for the Social Sciences) package program and the demographic characteristics of the participant group were analyzed through this program. The AMOS (Analysis of Moment Structures) program was used for confirmatory factor analysis of the scales and the designed model. The maximum likelihood estimation method was used to 
estimate model parameters in confirmatory factor analysis. RMSEA $(0-0,08)$, SRMR $(0-0.10)$, GFI (.90-1.00), CFI (.90-1.00), AGFI (.85-1.00), NFI (90-1.00), $\chi^{2} / s d=\mathrm{CMIN} / \mathrm{DF}(0-3)$ and significance level (p) fit indices were taken into account in the evaluation of model goodness of fit (Bayram, 2010; Reisinger \& Mavondo, 2007; Schermelleh-Engel et al., 2003; Şimşek, 2007). In this study, the lower limit of the factor loadings of the items in confirmatory factor analysis was accepted as .30. If there are few items in a scale prepared in the field of social sciences, the limit value for the factor load value can be reduced to .30 (Büyüköztürk, 2012). In addition, the assessment of normality for confirmatory factor analysis and structural equation modeling was based on a critical ratio below 10 .

\section{Research Results}

\section{Correlation Analysis}

The mean and standard deviation values of the variables (dependent and independent variables) in the study and the correlation coefficients between the independent and dependent variables are given in Table 2.

\section{Table 2}

Descriptive Statistics and Correlation Matrix of Constructs

\begin{tabular}{|c|c|c|c|c|c|c|c|c|c|c|c|c|}
\hline Constructs & $\overline{\mathbf{X}}$ & $S D$ & 1 & 2 & 3 & 4 & 5 & 6 & 7 & 8 & 9 & 10 \\
\hline 1. Habit & 3.20 & 0.77 & $(0.75)$ & & & & & & & & & \\
\hline 2. Understanding & 3.95 & 0.61 & $.23^{\star *}$ & $(0.79)$ & & & & & & & & \\
\hline 3. Reflecting & 3.96 & 0.67 & $.19^{* \star}$ & $.57^{\star \star}$ & $(0.73)$ & & & & & & & \\
\hline 4. Critical reflecting & 3.40 & 0.77 & $.33^{* *}$ & $.44^{* *}$ & $.45^{\star \star}$ & $(0.77)$ & & & & & & \\
\hline 5. Getting information & 4.12 & 0.58 & $.24^{* *}$ & $.50^{\star *}$ & $.52^{* *}$ & $.38^{* *}$ & $(0.79)$ & & & & & \\
\hline 6. Checking information & 3.81 & 0.65 & $.18^{* *}$ & $.32^{* *}$ & $.49^{* *}$ & $.47^{* *}$ & $.65^{\star *}$ & $(0.73)$ & & & & \\
\hline 7. Self confidence & 3.75 & 0.88 & $.23^{* *}$ & $.24^{* *}$ & $.23^{* *}$ & $.24^{* \star}$ & $.30^{\star *}$ & $.26^{\star \star}$ & $(0.74)$ & & & \\
\hline 8. Personal competence & 4.00 & 0.79 & $.13^{* *}$ & $.28^{* *}$ & $.35^{\star *}$ & $.27^{\star *}$ & $.37^{\star *}$ & $.20^{\star *}$ & $.20^{* *}$ & $(0.82)$ & & \\
\hline $\begin{array}{l}\text { 9. Teachers role in effective } \\
\text { teaching }\end{array}$ & 4.00 & 0.68 & $.13^{* *}$ & $.44^{* *}$ & $.46^{* *}$ & $.34^{* *}$ & $.57^{\star \star}$ & $.41^{* *}$ & $.19^{* *}$ & $.32^{* *}$ & $(0.83)$ & \\
\hline 10. Teaching performance & 4.04 & 0.70 & $.18^{* *}$ & $.44^{* *}$ & $.51^{* *}$ & $.38^{* *}$ & $.54^{* *}$ & $.53^{\star *}$ & $.16^{* *}$ & $.27^{\star *}$ & $.74^{* *}$ & $(0.80)$ \\
\hline
\end{tabular}

According to the data in Table 2, it is seen that prospective primary school teacher' perception levels of reflection in terms of reflective thinking dimensions $(\bar{X}=3.96)$ are higher than those of habit $(\bar{X}=3.20)$, understanding $(\bar{X}=3.95)$ and critical reflecting $(\bar{X}=3.40)$. In terms of inquiry skill dimensions, the highest average score was in the dimension of getting information $(\bar{X}=4.12)$, while the lowest average score was in the dimension of self-confidence $(\bar{X}=3.75)$. In terms of mathematics teaching self-efficacy belief dimensions, it is seen that the highest average score is in the dimension of performance related to teaching $(\bar{X}=4.04)$, while the lower and equivalent score averages are in the dimensions of personal competence $(\bar{X}=$ 4.00) and the role of the teacher in effective teaching $(\bar{X}=4.00)$. The relationships between the variables of the study are explained below:

1) Relationships between reflective thinking and inquiry skills: It is seen that the habit dimension of the reflective thinking scale has a positive and significant relationship with the dimensions of the inquiry skill scale such as getting information $(r=.24)$, checking information 
PROBLEMS

OF EDUCATION IN THE $21^{\text {st }}$ CENTURY Vol. 80 , No. 1,2022

220

$(r=.18)$ and self-confidence $(r=.23)$. Also, the understanding dimension of the reflective thinking scale has a positive and significant relationship with the dimensions of the inquiry skill scale such as getting information $(r=.50)$, checking information $(r=.32)$, and self-confidence $(r=.24)$; the reflection dimension of the reflective thinking scale has a positive and significant relationship with the dimensions of the inquiry skill scale such as getting information $(r=.52)$, checking information $(r=.49)$ and self-confidence $(r=.23)$. Finally, it is seen that the critical reflecting dimension of the reflective thinking scale has a positive and significant relationship with the dimensions of the inquiry skill scale such as getting information $(r=.38)$, checking information $(r=.47)$, and self-confidence $(r=.24)$. This shows that prospective primary school teachers with high reflective thinking skills will exhibit high inquiry skills.

2) Relationships between reflective thinking and mathematics teaching self-efficacy belief: It is seen that the habit dimension of the reflective thinking scale has a positive and significant relationship with the dimensions of the mathematics teaching self-efficacy belief scale such as personal competence ( $r=.13)$, the role of the teacher in effective teaching $(r=.13)$, and teaching performance $(r=.18)$; the understanding dimension of the reflective thinking scale has a positive and significant relationship with the dimensions of the mathematics teaching selfefficacy belief scale, such as personal competence $(r=.28)$, the role of the teacher in effective teaching $(r=.44)$, and teaching performance $(r=.44)$; the reflection dimension of the reflective thinking scale has a positive and significant relationship with the dimensions of the mathematics teaching self-efficacy belief scale such as personal competence $(r=.35)$, the role of the teacher in effective teaching $(r=.46)$, and teaching performance $(r=.51)$, Finally, the critical reflection dimension of the reflective thinking scale has a positive and significant relationship with the dimensions of the mathematics teaching self-efficacy belief scale, such as personal competence $(r=.27)$, the role of the teacher in effective teaching $(r=.34)$, and teaching performance $(r=$ .38). This shows that prospective primary school teachers with high reflective thinking skills will have higher mathematics teaching self-efficacy beliefs.

3) Relationships between inquiry skill and mathematics teaching self-efficacy belief: The getting information dimension of the inquiry skill scale appears to have a positive and significant relationship with the dimensions of the mathematics teaching self-efficacy belief scale, such as personal competence $(r=.37)$, the role of the teacher in effective teaching $(r=.57)$, and teaching performance $(r=.54)$, the inquiry skill scale's checking information dimension has a positive and significant relationship with the dimensions of the mathematics teaching self-efficacy belief scale, such as personal competence $(r=.20)$, the role of the teacher in effective teaching $(r=$ .41 ), and teaching performance $(r=.53)$. Finally, the self-confidence dimension of the inquiry skill scale seems to have a positive and significant relationship with the dimensions of the mathematics teaching self-efficacy belief scale, such as personal competence $(r=.20)$, the role of the teacher in effective teaching $(r=.19)$, and teaching performance $(r=.16)$. This shows that prospective primary school teachers with high inquiry skills will have higher mathematics teaching self-efficacy beliefs. Correlation analysis only reveals the level of correlation between structures. Structural equation model analyzes are required to understand the direct and indirect effects between the structures and even to reveal the mediating variables.

\section{Structural Equation Models}

In order to show the degree of influence of the variables of reflective thinking, inquiry skills and mathematics teaching self-efficacy beliefs under the title of structural equation models -and to understand the extent to which they explain each other, and to understand whether the inquiry skill is a mediating variable in the relationship between reflective thinking and mathematics teaching self-efficacy belief- two models were tested, namely "basic model" and "mediating model". 
Structural equation analysis was performed using covariance matrices according to maximum probability calculations. According to the results of the basic model shown in Figure 1, taking into account the MI (Modification Indices) values, the fit indices of the analyzed model were obtained as follows: $\mathrm{RMSEA}=.071$; $\mathrm{SRMR}=.071 ; \mathrm{CMIN} \backslash \mathrm{DF}=2,535 ; \mathrm{GFI}=.809$; $\mathrm{CFI}=.911 ; \mathrm{AGFI}=.879 ; \mathrm{NFI}=.904 ; \chi^{2}=1232,128 ; d f=486$ and $p=.000$. This result shows that the fit values of the model are acceptable and at the desired level (Bayram, 2010; Byrne, 2010; Kline, 2005; Şimşek, 2007).

The standardized beta, standard error and significance values of the path from the latent variable of reflective thinking to the latent variable of mathematics teaching self-efficacy belief are shown in Table 3. According to these findings, reflective thinking has a significant effect on mathematics teaching self-efficacy belief.

\section{Table 3}

\section{Path Coefficients of Basic Model}

\begin{tabular}{lllll}
\hline Path & Standardize $\boldsymbol{\beta}$ & SE & $\boldsymbol{p}$ \\
\hline $\begin{array}{l}\text { Reflective Thinking } \rightarrow \\
\text { Belief }\end{array}$ & Mathematics Teaching Self Efficacy & .73 & .03 & $* * *$ \\
\hline
\end{tabular}

Considering the standardized regression (Beta) coefficients in the model in Figure 1 obtained as a result of the analysis; reflective thinking has a positive effect on mathematics teaching self-efficacy belief $(\beta=0.73 ; p<.05)$. This result indicates the confirmation of the hypothesis of "Reflective thinking and mathematics teaching affect self-efficacy beliefs positively and significantly." in H1. In addition, it is seen that reflective thinking explains the mathematics teaching self-efficacy belief by 53\%. In other words, it can be said that the change in mathematics teaching self-efficacy beliefs of prospective primary school teachers depends on their reflective thinking perceptions at a rate of $53 \%$. This result confirms the hypothesis of "Reflective thinking and mathematics teaching explains self-efficacy belief significantly." in $\mathrm{H} 2$.

\section{Figure 1}

Model Diagram of The Effects of Reflective Thinking on Mathematics Teaching Self-Efficacy Belief

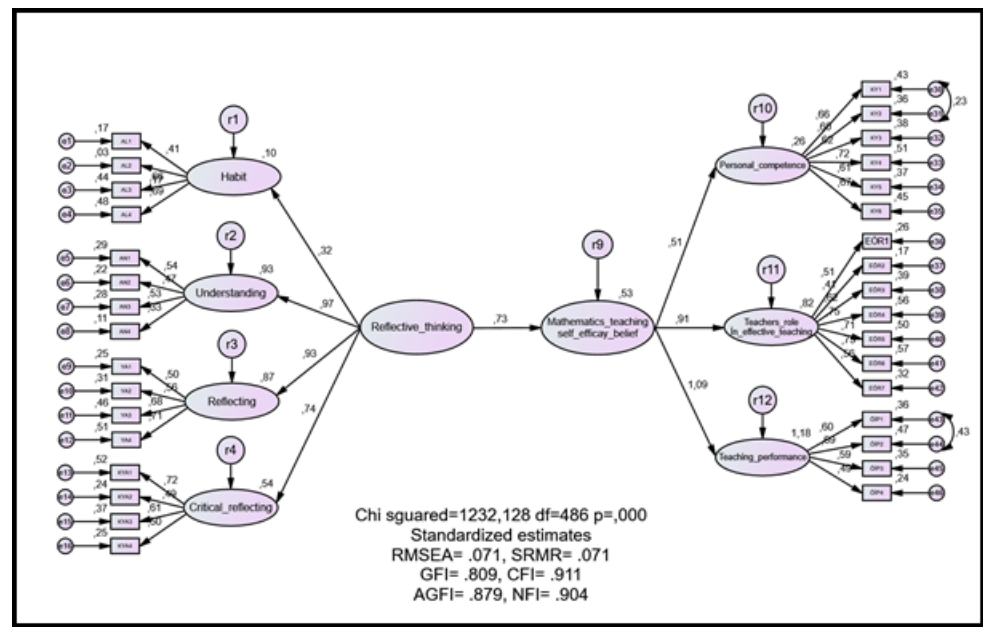


PROBLEMS

OF EDUCATION

IN THE $21^{\text {st }}$ CENTURY

Vol. 80 , No. 1,2022

222

\section{Mediating Model Results}

In the mediating model shown in Figure 2, one of the structural equation models, the latent variable of reflective thinking was taken as independent, the latent variable of mathematics teaching self-efficacy belief was taken as the dependent variable, and the latent variable of questioning ability was taken as the mediating variable. Thus, both the existence of the effects related to the mediating role and the accuracy of the research hypotheses were investigated.

According to the results of the mediating model shown in Figure 2, the fit indices of the analyzed model -taking into account the MI (Modification Indices) values- were obtained as follows: $\mathrm{RMSEA}=.071 ; \mathrm{SRMR}=.690 ; \mathrm{CMIN} \backslash d f=2,525 ; \mathrm{GFI}=.848 ; \mathrm{CFI}=.907$; $\mathrm{AGFI}=.896$; $\mathrm{NFI}=.889 ; \chi^{2}=2573,241 ; d f=1019$ and $p=.000$. This result shows that the fit values of the model are acceptable and at the desired level. The standardized beta, standard error and significance values of the paths specified in the model are shown in Table 4.

Table 4

Path Coefficients of Mediation Model

\begin{tabular}{llll}
\hline Path & Standardize $\beta$ & SE & $p$ \\
\hline Reflective thinking $\rightarrow$ Inquiry skill & .95 & .04 & $* * *$ \\
Reflective thinking $\rightarrow$ Mathematics teaching self-efficacy belief & .44 & .04 & $* * *$ \\
Inquiry skill $\rightarrow \quad$ Mathematics teaching self-efficacy belief & .40 & .05 & $* * *$ \\
\hline
\end{tabular}

According to these findings, the perception of reflective thinking significantly affects the perception of inquiry skills (standardized $\beta=0.95 ; p<.05$ ), and the perception of inquiry skills significantly affects mathematics teaching self-efficacy belief (standardized $\beta=0.40 ; p<.05$ ). In addition to all these, the effect of reflective thinking on mathematics teaching self-efficacy belief decreased with the inclusion of inquiry skills in the model (standardized $\beta=0.44 ; p<.05$ ). This result shows the correctness of the hypothesis of "Inquiry skill has a partial mediation effect between reflective thinking and mathematics teaching self-efficacy belief' in $\mathrm{H7}$. 
Figure 2

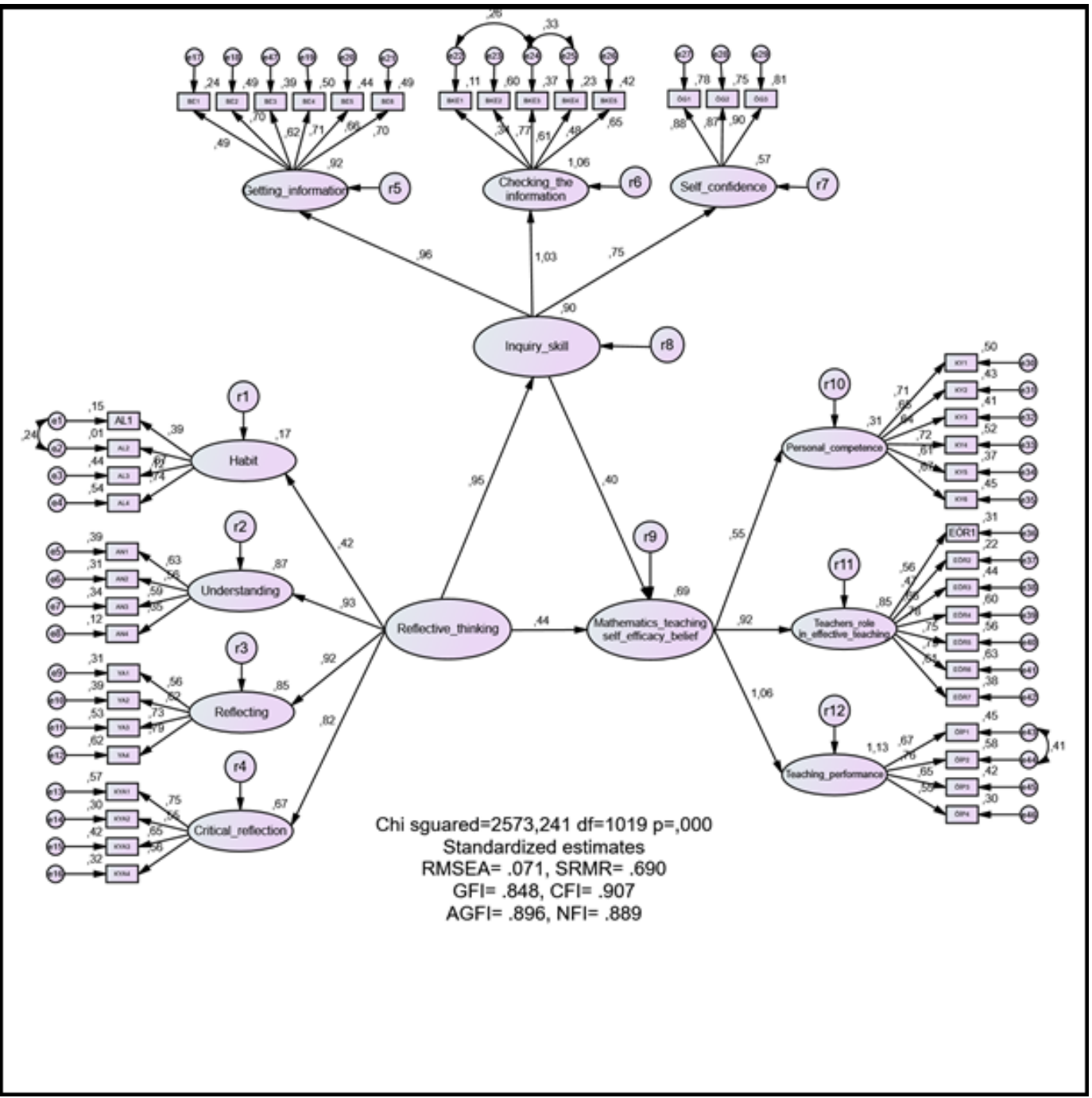

Considering the other hypotheses of the research, the following results were obtained:

Considering the standardized regression (Beta) coefficients in the model obtained as a result of the research and in Figure 2, it is seen that reflective thinking has a positive and significant effect on the inquiry skill $(\beta=0.95 ; p<.05)$. This result confirms the hypothesis of "Reflective thinking positively and significantly affects the inquiry skill." in $\mathrm{H} 3$. In addition, when we look at the level of reflective thinking explaining the inquiry skill, it is seen that reflective thinking explains the inquiry skill by $90 \%$. In other words, it can be said that $90 \%$ of the change in prospective primary school teachers' perceptions of inquiry skills depends on their reflective thinking levels. This result confirms the hypothesis of "Reflective thinking meaningfully explains the inquiry skill." in H4.

Regarding the fifth hypothesis of the study, when the standardized regression (Beta) coefficients in the model are examined, it is understood that inquiry skill has a positive and 
PROBLEMS

OF EDUCATION IN THE $21^{\text {st }}$ CENTURY Vol. 80 , No. 1,2022

224

significant effect on mathematics teaching self-efficacy belief $(\beta=0.40 ; p<.05)$. This result demonstrates the accuracy of the hypothesis stated in H5 that "Inquiry skill affects mathematics teaching self-efficacy belief positively and significantly". Another finding that stands out in the model proposed above is that the latent variables of reflective thinking and inquiry skills together explain the latent variable of mathematics teaching self-efficacy belief as significant at the rate of $69 \%$. In other words, it was revealed that the change in mathematics teaching self-efficacy beliefs of prospective primary school teachers was related to their perceptions of reflective thinking and inquiry skills at a rate of $69 \%$. This finding shows that reflective thinking and inquiry skills are important predictors on mathematics teaching self-efficacy belief. This result reveals the accuracy of the hypothesis in H6 that "Reflective thinking and inquiry skills together explain mathematics teaching self-efficacy belief at a high level and meaningfully".

\section{Discussion}

This study aims to show to what extent the variables of reflective thinking, inquiry skill and mathematics teaching self-efficacy belief affect each other, to show their rates of explaining each other, and to show whether inquiry skill is a mediating variable in the relationship between reflective thinking and mathematics teaching self-efficacy belief. In this context, the study discussed the effects of prospective primary school teachers' reflective thinking, inquiry skills, and mathematics teaching self-efficacy belief levels on each other and their levels of explaining each other.

Teachers need to learn new skills such as problem-solving, creativity, critical thinking, cooperation, and communication, which are accepted as 21 st-century skills, both in terms of improving the quality and reflecting this on student outcomes. Regarding the first and second hypotheses of the study, it was found that reflective thinking affected and explained mathematics teaching self-efficacy belief positively and significantly. It was also found that reflective thinking explained mathematics teaching self-efficacy belief by $53 \%$. In other words, high reflective thinking has a positive effect on prospective primary school teachers' mathematics teaching self-efficacy belief. Reflective thinking skill shows that the teacher is confident about his/her mathematics teaching skills. It also enables prospective teachers to be open to new ideas, improve their classroom behaviors and to develop positive attitudes towards teaching. It is important for prospective primary school teachers who may encounter many problems in their professional lives to have high self-efficacy beliefs since they will struggle to overcome these obstacles. Prospective teachers with high mathematics self-efficacy perceptions are expected to become persistent teachers, who can deal with problems, and who do not give up easily after they graduate. Unlike this study, Gözel and Toptaş (2017) found a significant and positive weak correlation between prospective primary school teachers' self-efficacy beliefs about mathematics teaching and their reflective thinking skills. According to this, it can be said that participants carry out low levels of reflective thinking during mathematics teaching practices. In Sevgi and Zihar's (2020) study, a moderate, positive, and significant correlation was found between secondary school students' reflective thinking skills related to problem-solving and their mathematics self-efficacy perception. Demirtaş and Menşan (2021) found a positive and significant correlation between prospective primary school teachers' high-level thinking skills and their problem-solving beliefs. Tunç and Kincal (2021) found a positive moderate correlation between preschool teachers' reflective thinking tendencies and their self-efficacy beliefs. Regarding the effect of self-efficacy on reflection, Thoonen et al. (2011) observed that teachers' self-efficacy beliefs were the strongest motivation in explaining teachers' experiences and reflections. Reflection is considered an important tool in the professional development of teachers (Burton, 2009). In a study conducted on prospective teachers, Norton (1997) found a positive association between effective teaching and reflective thinking. The development 
of reflective thinking forms the center of mathematics teaching (Meissner, 2006). Therefore,

gaining reflective thinking skills seems to be important in mathematics teaching. In literature, it has been shown that reflective thinking is important in terms of mathematics teaching (García et al., 2007; Kramarski et al., 2013) and reflective thinking supports significant learning in mathematics (Inoue \& Buczynski, 2011; McNaught, 2010). Thus, it can be said that prospective teachers with high reflective thinking skills will have high mathematics teaching self-efficacy beliefs.

In mathematics lessons, teachers should guide their students to think reflectively during the problem-solving process, and they should ensure that their students question and evaluate what they do and establish cause-effect relationships between events and concepts. It is important to investigate the reflective thinking skills of prospective teachers which will enable them to think about parts they find themselves competent and incompetent by questioning what they will teach and why during their teaching process in terms of their professional development (Dewey, 1933; Schön, 1983). Regarding the third and fourth hypotheses of the study, it was concluded that reflective thinking explained $90 \%$ of inquiry skills. Therefore, teachers can make use of inquiry to develop students' reflective skills. Similar to this result, Dindar (2018) found a positive and significant correlation between prospective teachers' inquiry skills and their reflective thinking tendencies. Individuals who have reflective thinking skills can associate thoughts about their previous/present and future experiences, they can question, they can evaluate themselves and situations and they responsible for their learning as a part of the learning experience. Reflective thinking is a skill that can be developed by using various methods (Wilson \& Jan, 1993). Taggart and Wilson (2005) claimed that teachers' reflective thinking skills can be developed by using techniques such as brainstorming, cooperating with others, and inquiry. However, it is important for a teacher who wants to develop students' reflective thinking skills to have these skills because teachers who have reflective thinking skills support and guide their students (Wilson \& Jan, 1993). Reflective thinking is generally the result of teaching (Meissner, 2006). Teachers with reflective teaching can prepare a teaching environment suitable for their students' needs by preparing reflective thinking environments. According to Ersözlü and Kazu (2011), as with many other skills, the earlier reflective thinking is acquired, the more effective it can be. For this reason, starting from primary education, students should be taught these skills and thus a basis should be prepared for students to improve these skills in their future school life.

Regarding the fifth hypothesis of the study, it was concluded that inquiry skills affected mathematics teaching self-efficacy belief positively and significantly. Therefore, prospective teachers' inquiry skills have a positive effect on their mathematics teaching competence. This is because while questioning themselves, individuals compare previous knowledge with what they learn, they activate their prior knowledge, see their weaknesses and strengths in understanding the subject and think about how they can complete these in the best way. While performing a task, they see the steps they follow the methods they use, and the advantages and disadvantages of these and evaluate them. To be able to use inquiry effectively, teachers should tailor the questions according to students' level, needs and in parallel with the subject. Considering the students that prospective primary school teachers will educate in the future, prospective teachers will need to have high inquiry skills and include inquiry-based practices frequently in their classes. This is because with inquiry-based experiences, skills are internalized, and these skills become a part of students' mental structure. For this reason, for meaningful learning to occur, students should be provided with the opportunity to experience something and thus knowledge and skills should be internalized.

Regarding the sixth and seventh hypotheses of the study, it was concluded that reflective thinking and inquiry skill together explained mathematics teaching self-efficacy belief significantly with a rate of $69 \%$. This result shows that reflective thinking and inquiry skill are significant predictors (explanatory) of inquiry skills. Therefore, prospective primary school 
PROBLEMS

OF EDUCATION

IN THE $21^{\text {st }}$ CENTURY Vol. 80, No. 1,2022

226

teachers' being individuals with reflective thinking and inquiry skills affect their mathematics teaching competence significantly. Mathematics teaching self-efficacy belief of prospective primary school teachers is individuals' belief in their abilities and capacity. Self-efficacy belief shows that prospective primary school teachers consider themselves competent about mathematics teaching and they believe that they can teach effectively. Mathematics teaching self-efficacy belief of prospective primary school teachers expresses teachers' beliefs that they will show the required behaviors so that they can successfully perform the teaching process. It is possible for primary school teachers, who will teach basic knowledge and skills in mathematics teaching to their students, to educate their students as reflective thinking and questioning individuals through including reflective thinking and inquiry in mathematics teaching. It can be said that teachers who have the desired self-efficacy belief have a high level of satisfaction, they tend to their profession more, they trust their teaching ability, they perform their teaching functions more successfully, they believe that learning can be affected by effective teaching, they can persist for a longer time by experiencing professional stress less, and they can provide different feedback to students who have difficulty in education and learning.

\section{Suggestions}

It is thought that in terms of conducting a more detailed identification of causes that affect the reflective thinking and inquiry skills of prospective teachers, using qualitative data such as observations and interviews in addition to quantitative data will develop a multi-dimensional perspective. For this reason, it seems to be important to conduct studies in which qualitative data are obtained. The general objective of teacher education programs is to create behavioral changes in prospective teachers that can be reflected on their students. For this reason, it can be recommended for academic staff educating prospective teachers to improve themselves about reflective thinking and inquiry skills. It seems important to provide practical training for future teachers in faculties of education to develop their reflective thinking and inquiry skills. In faculties of education, educational programs should be prepared to develop reflective thinking and inquiry skills in prospective teachers. It is an important requirement for teachers to gain reflective thinking skills in prospective primary school teachers training since reflective thinking training will enable prospective teachers to develop both their own and their future students' reflective thinking skills in their professional practice.

\section{Conclusions}

Reflective thinking and mathematics teaching affect self-efficacy beliefs positively and significantly. Reflective thinking and mathematics teaching explains self-efficacy belief significantly. Reflective thinking positively and significantly affects the inquiry skill. Reflective thinking meaningfully explains the inquiry skill. Inquiry skill affects mathematics teaching self-efficacy belief positively and significantly. Reflective thinking and inquiry skills together explain mathematics teaching self-efficacy belief at a high level and meaningfully. Inquiry skill has a partial mediation effect between reflective thinking and mathematics teaching selfefficacy belief.

\section{References}

Abdi, A. (2014). The effect of inquiry-based learning method on students' academic achievement in science course. Universal Journal of Educational Research, 2(1), $37-$ 41. https://doi.org/10.13189/ujer.2014.020104 
Akar, D., \& Şahin, Ç. (2020). Sınıf öğretmenlerinin yansıtıcı düşünme eğilimleri [Reflective thinking dispositions of experienced and novice classroom teachers]. Ahi Bilge Eğitim Dergisi, 1(1), 15-32.

Akay, H., \& Boz, N. (2011). Sınıf öğretmeni adaylarının matematiğe yönelik tutumları, matematiğe karşı öz-yeterlik algıları ve öğretmen öz-yeterlik inançları arasındaki ilişkilerin incelenmesi [Examining the relationships among prospective primary school teachers' attitude towards mathematics, mathematics self-efficacy beliefs, teacher self-efficacy beliefs]. The Journal of Turkish Educational Sciences, 9(2), 281-312.

Akpullukçu, S. (2011). Fen ve teknoloji dersinde araştırmaya dayalı öğrenme ortamının öğrencilerin akademik başarl, hatırda tutma düzeyi ve tutumlarına etkisi [The effect of inquiry-based learning environment in science and technology course on the students' academic achievements, attitudes and retention level] [Unpublished master's thesis]. University of Dokuz Eylül.

Aldan-Karademir, Ç., \& Saracaloğlu, A. S. (2013). Sorgulama becerileri ölçeği’nin geliştirilmesi: Geçerlik ve güvenirlik çalışması [The development of inquiry skills scale: Reliability and validity study]. Asian Journal of Instruction, 1(2), 56-65.

Alkan, V., \& Gözel, E. (2013). Sınıf öğretmeni adaylarının yansıtıcı düşünme becerilerine ilişkin görüşleri [The prospective primary school teachers' views about reflective thinking skills]. e-Journal of New World Sciences Academy, 8(1), 1-12.

Aras, B., Şiringül, İ., \& Park, F. (2019). Öğretmen adaylarının yansıtıcı düşünme düzeylerinin bazı değişkenlere göre incelenmesi [Investigating reflective thinking levels of prospective teachers according to some variables]. International Journal of Science and Education, 1(2), 119-130.

Arseven, A., Arseven, İ., \& Tepehan, T. (2015). Sınıf öğretmeni adaylarının matematik öğretimine yönelik öz-yeterlik algılarının incelenmesi [Examination of class teacher candidates' mathematics teaching self-efficacy]. Cumhuriyet International Journal of Education, 4(2), 2940. https://doi.org/10.30703/cije.321367

Bağcaz, E. (2009). Sorgulayıcı öğretim yönteminin öğrencilerin akademik başarısı ve fen ve teknoloji dersine yönelik tutumuna etkisi [The effect of inquiry teaching method on students' academic success and on attitude for the science and technology lesson] [Unpublished master's thesis]. University of Sakarya.

Balım, A. G., İnel, D., \& Evrekli E. (2008). Fen öğretiminde kavram karikatürü kullanımının öğrencilerin akademik başarılarına ve sorgulayıcı öğrenme becerileri algılarına etkisi [The effects the using of concept cartoons in science education on students' academic achievements and enquiry learning skill perceptions]. Elementary Education Online, 7(1), 188-202.

Baş, G., \& Kıvılcım, Z. S. (2013). Lise öğrencilerinin problem çözmeye yönelik yansıtıcı düşünme becerileri ile matematik ve geometri derslerindeki akademik başarıları arasındaki ilişki [The correlation between reflective thinking skills towards problem solving and academic success in mathematics and geometry courses of high school students]. Ahi Evran University Journal of Kirşehir Education Faculty, 14(3), 1-17.

Başol, G., \& Evin-Gencel, İ. (2013). Yansıtıcı düşünme düzeyini belirleme ölçeği: Geçerlik ve güvenirlik çalışması [Reflective thinking scale: A validity and reliability study]. Educational Sciences: Theory \& Practice, 13(2), 929-946.

Bayram, N. (2010). Yapısal eşitlik modellemesine giriş: Amos uygulamaları. [Introduction to structural equation modeling: Amos applications]. Ezgi Publishing.

Bell, R. L., Smetana, L., \& Binns, I. (2005). Simplifying inquiry instruction. The Science Teacher, 72(7), $30-33$.

Birgin, O. (2016). Matematik öğrenmeye ilişkin inanç ölçeğinin geliştirilmesi: Geçerlik ve güvenirlik çalışması [Development of the belief scale towards mathematics learning: A study of validity and reliability] Proceedings of first INES International Academic Research Congress (pp. 3916-3923). Pegem Academy Publishing.

Branch, J. L., \& Solowan, D. G. (2003). Inquiry-based learning: The key to student success. School Libraries in Canada, 22(4), 6-12.

Budak Bayır, E. (2008). Fen müfredatlarındaki yeni yönelimler ışı̆̆ında öğretmen ĕgitimi: Sorgulayıcıaraştırma odakl kimya ögretimi [Teacher education in the light of new tendencies in science curriculum: Inquiry-based chemistry teaching] [Unpublished doctoral dissertation]. University of Gazi. 
PROBLEMS

OF EDUCATION IN THE $21^{\text {st }}$ CENTURY Vol. 80, No. 1,2022

Burton, J. (2009). Reflective practice. In A. Burns, \& J. C. Richards (Eds.), The Cambridge guide to second language teacher education (pp. 298-307). Cambridge University Press.

Büyüköztürk, Ş. (2012). Sosyal bilimler için veri analizi el kitabı. [Manual of data analysis for social sciences]. Pegem Academy Publications.

Byrne, B. M. (2010). Structural equation modeling with AMOS: Basic concepts, applications and programming. Taylor and Francis Group.

Chung, H. M., \& Behan, K. J. (2010). Peer sharing facilitates the effect of inquiry-based projects on science learning. The American Biology Teacher, 72(1), 24-29. https://doi.org/10.1525/abt.2010.72.1.7

Çağırgan-Gülten, D., Özsoy-Güneş, Z., \& Kırbaşlar, F. G. (2012, September 12-14). Matematik özyeterlik algısının çeşitli değişkenler açısından değerlendirilmesine yönelik bir çalışma [A study to evaluate the perception of mathematics self-efficacy in terms of various variables] [Conference presentation] X. UFBMEK National Science and Mathematics Education Congress, İstanbul, Turkey.

Çelik, B. B., \& Dikmenli, Y. (2021). Sınıföğretmeni adaylarının yaratıcı ve yansıtıcı düşünme eğilimlerinin incelenmesi [Investigating creative and reflective thinking trends of class teacher candidates]. Anadolu Kültürel Araştırmalar Dergisi, 5(1), 46-65. https://doi.org/10.15659/anka d.v5i1.101

Çeliksöz, M. (2012). Farklı düzeylerdeki sorgulayıcı-araştırmaya dayalı ögretim yöntemlerinin ilköğretim ögrencilerinin başarı, tutum, bilimsel süreç becerisi ve bilgi kalıcılıklarına etkileri [The effects of inquiry-based teaching methodologies at different levels on primary school students' achievement, attitudes, scientific process skills and retention of knowledge] [Unpublished master's thesis]. University of Trakya.

Davies, D. J., Collier, C., \& Howe, A. (2012). A matter of interpretation: Developing primary pupils' enquiry skills using position-linked datalogging. Research in Science \& Technological Education, 30(3), 311-325. https://doi.org/10.1080/02635143.2012.738420

Demirtaş, B., \& Menşan, N. Ö. (2021). Sınıf öğretmeni adaylarının üst düzey düşünme becerileri ile problem çözmeye ilişkin inançları arasındaki ilişki [The relationship between the high-level thinking skills and the faith of problem-solving of the primary school teacher candidates]. International Journal of Primary Education Studies, 2(1), 43-52.

Dewey, J. (1933). How we think. A restatement of the relation of reflective thinking to the educative process. Heath \& Co Publishers.

Dindar, S. (2018). Okul öncesi öğretmen adaylarının sorgulama becerileri ile yansıtıcı düşünme eğilimleri asasindaki ilişkinin incelenmesi [Examining the relationship between inquiry skills of preschool teacher candidates and reflective thinking tendencies] [Unpublished master's thesis]. University of Okan.

Duban, N. (2008). Illköğretim fen ve teknoloji dersinin sorgulamaya dayalı öğrenme yaklaşımına göre işlenmesi: Bir eylem araştırması [Conducting science and technology course through inquirybased learning approach in primary education: An action research] [Unpublished doctoral dissertation]. University of Anadolu.

Enochs, L., Smith, P. L., \& Huinker, D. (2000). Establishing factorial validity of the mathematics teaching efficacy beliefs instrument. School Science and Mathematics, 100(4), 194-202. https://doi.org/10.1111/j.1949-8594.2000.tb17256.x

Erdoğan, M. N. (2005). İlkögretim 7. sınıf ögrencilerinin atomun yapısı konusundaki başarılarına, kavramsal değişimlerine, bilimsel süreç becerilerine ve fene karşı tutumlarına sorgulayıcıaraştırma yönteminin etkisi [The effects of inquiry method on middle school (level 7) students' achievement, conceptual change, scientific process skills and attitude toward science about the atomic structure] [Unpublished master's thesis]. University of Gazi.

Ersözlü, Z. N., \& Kazu, H. (2011). İlköğretim beşinci sınıf sosyal bilgiler dersinde uygulanan yansıtıcı düşünmeyi geliştirme etkinliklerinin akademik başarıya etkisi [The effects of reflective thinking activities on the academic successes of fifth grade primary social studies students]. Journal of Uludag University Faculty of Education, 24(1), 141-159.

Evrekli, E. (2010). Fen ve Teknoloji öğretiminde zihin haritası ve kavram karikatürü etkinliklerinin ögrencilerin akademik başarılarına ve sorgulayıcı ögrenme becerileri algılarına etkisi [The effects of mind map and concept cartoon activities in science and technology education on students' academic achievement and inquiry learning skill perceptions] [Unpublished master's thesis]. University of Dokuz Eylül. 
Evren, B. (2012). Fen ve teknoloji ögretiminde sorgulayıcı öğrenme yaklaşımının öğrencilerin sahip oldukları eleştirel düşünme eğilim düzeylerine ve fen ve teknoloji dersine yönelik tutumlarına etkisi [The effect of inquiry learning approach on elementary students' critical thinking dispositions and attitudes towards science and technology course] [Unpublished master's thesis]. University of Adnan Menderes.

García, M., Sánchez, V., \& Escudero, I. (2007). Learning through reflection in mathematics teacher education. Educational Studies in Mathematics, 64(1), 1-17. https://doi.org/10.1007/s10649-006-9021-9

Gençtürk, H. A. (2004). Sorgulama yöntemiyle fen bilgisi dersi ögrretiminin ilköğretim okullarında uygulaması [Teaching elementary science courses with inquiry-teaching method at the primary schools] [Unpublished master's thesis]. University of Afyon Kocatepe.

Gipe, J. P., \& Richards, J. C. (1992). Reflective thinking and growth in novices' teaching abilities. Journal of Educational Research, 86(1), 52-57. https://doi.org/10.1080/00220671.1992.9941827

Gözel, E., \& Toptaş, V. (2017). Sınıf öğretmeni adaylarının matematik öğretimi yeterlik inançları ile yansıtıcı düşünme becerileri arasındaki ilişki [The relationship between mathematical teaching efficacy beliefs and reflective thinking skills of prospective primary school teachers]. Cumhuriyet International Journal of Education, 6(4), 412-425. https://doi.org/10.30703/cije.327172

Güngör Seyhan, H. (2008). Kimya eğitiminde sorgulamaya dayalı ögrenci deneylerinin geliştirilmesi ve sonuçlarının tartışılması [Developing inquiry-based student experiments in the chemistry education and discussing results] [Unpublished master's thesis]. University of Gazi.

Hacıömeroğlu, G., \& Şahin-Taşkın, Ç. (2010). Sınıf öğretmeni adaylarının matematik öğretimi yeterlik inançları [Elementary preservice teachers' mathematics teaching efficacy belief]. Journal of Uludag University Faculty of Education, 23(2), 539-555.

Hair, J. F., Anderson, R. E., Tatham, R. L., \& Black, W. C. (1998). Multivariate data analysis (5th ed.). Prentice-Hall International.

Inoue, N., \& Buczynski, S. (2011). You asked open-ended questions, now what? Understanding the nature of stumbling blocks in teaching inquiry lessons. The Mathematics Educator, 20(2), 10-23.

Kaf-Hasırcı, Ö., \& Sadık, F. (2011). Sınıf öğretmenlerinin yansıtıcı düşünme eğilimlerinin incelenmesi [Examining the reflective thinking dispositions of classroom teachers]. Çukurova University Journal of Social Sciences, 20(2), 195-210.

Kara, K. (2008). Illköğretim 3. sinıf hayat bilgisi dersinde sorgulama merkezli etkinliklerle yapılan proje çalışmalarındaki ögrenci performansının değerlendirilmesi [The evaluation of student performance on the projects which are based on inquiry in the third-grade life studies course] [Unpublished master's thesis]. University of Çukurova.

Karapınar, A. (2016). Sorgulamaya dayalı öğrenme ortamının öğretmen adaylarının bilimsel süreç becerileri, sorgulama becerileri ve bilimsel düşünme yetenekleri üzerindeki etkisi [The impact of inquiry-based learning environment on scientific process skills, inquiry skills and scientific reasoning skills of prospective schoolteachers] [Unpublished master's thesis]. University of Celal Bayar.

Karasar, N. (2012). Bilimsel araştırma yöntemi [Scientific research method]. Nobel Publishing.

Kember, D., Leung, D., Jones, A., Loke, A., McKay, J., Sinclair, K., Tse, H., Webb, C., Wong, F., Wong, M., \& Yeung, E. (2000). Development of a questionnaire to measure the level of reflective thinking. Assessment and Evaluation in Higher Education, 25(4), 381-395. https://doi.org/10.1080/713611442

Kızılkaya, G., \& Aşkar, P. (2009). Problem çözmeye yönelik düşünme becerisi ölçeğinin geliştirilmesi [The development of a reflective thinking skill scale towards problem solving]. Education and Science, 34(154), 82-92.

Kramarski, B., Weiss, I., \& Sharon, S. (2013). Generic versus context-specific prompts for supporting selfregulation in mathematical problem solving among students with low or high prior knowledge. Journal of Cognitive Education and Psychology, 12(2), 197-214. https://doi.org/10 .1891/19458959.12.2.197

Küçük, H. (2012). İlköğretimde bilimsel tartışma destekli sınıf içi etkinliklerin kullanılmasının ögrencilerin kavramsal anlamalarına, sorgulayıcı ögrenme becerileri algilarına ve fen ve teknolojiye yönelik tutumlarina etkisi [The effect of using argumentation supported classroom activities in elementary education on students' conceptual understandings, inquiry learning skill perceptions and attitudes towards science and technology] [Unpublished master's thesis]. University of Muğla Sitk1 Koçman. 
PROBLEMS

OF EDUCATION IN THE $21^{\text {st }}$ CENTURY Vol. 80, No. 1,2022

Lawson, A. E. (2010). Teaching inquiry science in middle and secondary schools. Sage Publications.

Llewellyn, D. (2002). Inquiry within: Implementing inquiry-based science standards. Corwin Press.

Mahnaz, M. (1997). Content and nature of reflective teaching: A case of an experiment middle school science teacher. Clearing House, 70(3), 143-151. https://doi.org/10.1080/00098655.1997.10543914

McNaught, K. (2010). Reflective writing in mathematics education programmes. Reflective Practice, 11(3), 369-379. https://doi.org/10.1080/14623943.2010.487373

Meissner, H. (1999, July 15-19). Creativity and mathematics education [Conference presentation]. Creativity and Mathematics Education of the International Conference, Muenster, Germany.

Ministry of National Education [MoNE]. (2018). Milli Eğitim Bakanlığı Talim ve Terbiye Kurulu Başkanlığı Matematik Dersi Öğretim Programı [Ministry of National Education Board of Education and Training mathematics curriculum], Ankara.

Norton, J. L. (1997). Locus control and reflective thinking in preservice teachers. Education, 117(3), 401-410.

Reisinger, Y., \& Mavondo, F. (2007). Structural equation modeling: Critical issues and new developments. Journal of Travel \& Tourism Marketing, 21(4), 41-71. https://doi.org/10.1300/J0 73v21n04_05

Sağlam, S. (2012). Lisans öğrencilerinin RNA teknolojileri konusundaki bilgi seviyeleri ve sorgulamaya dayalı öğrenme yaklaşımıyla sunulan materyalin etkisi [Knowledge levels of undergraduate students about RNA technologies and the effect of materials presented through inquiry-based learning approach] [Unpublished master's thesis]. University of Gazi.

Schermelleh-Engel, K., Moosbrugger, H., \& Müller, H. (2003). Evaluating the fit of structural equation models: Tests of significance and descriptive goodness-of-fit measures. Methods of Psychological Research Online, 8(2), 23-74.

Schön, D. (1987). Educating the reflective practitioner: Toward a new design for teaching and learning in the professions. Jossey Bass.

Sevgi, S., \& Zihar, M. (2020). Ortaokul öğrencilerinin yansıtıcı düşünme becerileri ile matematik öz yeterlik algılarının çeșitli değişkenler açısından incelenmesi [Analyzing the reflective thinking skills and mathematical self-efficacy perceptions of middle school students with respect to some variables]. Kastamonu Education Journal, 28(6), 2331-2345. https://doi.org/10.24106/kefdergi.700428

Sözen, K. (2010). Sorgulayıcı ögrenme ve programl ögretim yöntemlerine göre işlenen biyoloji laboratuvarı uygulamalarının karşılaştırılması [The comparison of biology laboratory applications done according to inquiry learning and programmed teaching] [Unpublished master's thesis]. University of Sakarya.

Swars, S., Hart, L. C., Smith, S. Z., Smith, M. E., \& Tolar, T. A. (2007). Longitudinal study of elementary pre-service teachers' mathematics beliefs and content knowledge. School Science and Mathematics, 107(9), 325-335. https://doi.org/10.1111/j.1949-8594.2007.tb17797.x

Şen, H. C. (2010). Bir öğrenci özellikleri-uygulama etkileşimi çalışması: sorgulama temelli öğretim ve düz anlatım metotlarlyla ögretimin lise ögrencilerinin fizik başarısı üzerindeki etkisi [An aptitude treatment interaction study: The effect of inquiry-based instruction and lecture instruction on high school students' physics achievement] [Unpublished doctoral dissertation]. Middle East Technical University.

Şimşek, Ö. F. (2007). Yapısal eşitlik modellemesine giriş. Temel ilkeler ve LISREL uygulamaları [Introduction to structural equation modeling. Basic principles and applications of LISREL]. Ekinoks Publications.

Taggart, G. L., \& Wilson, A. P. (2005). Promoting reflective thinking in teachers: 50 action strategies. Corwin Press.

Taşkoyan, S. N. (2008). Fen ve teknoloji öğretiminde sorgulayıcı öğrenme stratejilerinin ögrrencilerin sorgulayıc öğrenme becerileri, akademik başarıları ve tutumları üzerindeki etkisi [The effect of inquiry learning strategies on students' skills of inquiry learning, academic success and attitudes] [Unpublished master's thesis]. University of Dokuz Eylül.

Thoonen, E. E. J., Sleegers, P. J. C., Oort, F. J., Peetsma, T. T. D., \& Geijsel, F. P. (2011). How to improve teaching practices: The role of teacher motivation, organizational factors, and leadership practices. Educational Administration Quarterly, 47(3), 496536. https://doi.org/10.1177/0013161X11400185

Timur, B. (2005). İlköğretim 7. sinıf fen bilgisi dersinde sorgulamalı öğretimin öğrenci başarısına etkisi [The effect of inquiry teaching on student achievement in 7th grade science courses] [Unpublished master's thesis]. University of Çanakkale Onsekiz Mart. 
Toluk-Uçar, Z., Pişkin, M., Akkaş, E. N., \& Taşçı, D. (2010). İlköğretim öğrencilerinin matematik, matematik öğretmenleri ve matematikçiler hakkındaki inançları [Elementary students' beliefs about mathematics, mathematics' teachers and mathematicians]. Education and Science, 35(155), 131-144.

Tunç, Y., \& Kıncal, R. Y. (2021). Okul öncesi öğretmenlerinin yansıtıcı düşünme eğilimleri ile öz yeterlik inançları arasındaki ilişkinin incelenmesi [Investigation of the relationship between reflective thinking tendencies and self-efficiency beliefs of preschool teachers]. The Journal of Academic Social Science, 9(113), 249-267. http://dx.doi.org/10.29228/ASOS.48926

Varlı, B., \& Uluçınar-Sağır, Ş. (2019). Araştırma sorgulamaya dayalı öğretimin ortaokul öğrencilerinin fen başarısı, sorgulama algısı ve üstbiliş farkındalığına etkisi [The effect of inquirybased teaching on secondary school students' science success, questioning perception and metacognitive awareness]. Gazi University Journal of Gazi Educational Faculty, 39(2), 703 725. https://doi.org/10.17152/gefad.407417

Wilson, J., \& Jan, L. W. (1993). Thinking for themselves: Developing strategies for reflective learning. Eleanor Curtain Publishing.

Yıldırım, A., \& Şimşek, H. (2013). Sosyal bilimlerde nitel araştırma yöntemleri [Qualitative research methods in the social sciences]. Seçkin Publishing.

Received: October 23, 2021

Accepted: January 24, 2022

Cite as: Saracoglu, M. (2022). Reflective thinking and inquiry skills as predictors of selfefficacy in teaching mathematics. Problems of Education in the $21^{\text {st }}$ Century, 80(1), 213-231. https://doi.org/10.33225/pec/22.80.213

Mehtap Saracoglu

$\mathrm{PhD}$, Assistant Professor, Faculty of Education, Siirt University, Kezer Kampüsü, 56100, Merkez, Siirt, Turkey.

E-mail: mehtapsarac@siirt.edu.tr

ORCID: http://orcid.org/0000-0002-2460-9529 